\title{
Solid-Phase Synthesis and In Vitro Cytotoxicity of New Peptide Functionalized Cyclencarboxymethylen and L-DOPA Hybrids
}

\author{
L Arabuli ${ }^{1,2 *}$, R Jezek ${ }^{3}$, T Macek ${ }^{3}$, P Lovecka ${ }^{3}$, E Nikoleishvili ${ }^{1}$, N Sulashvili ${ }^{1}$ and I Maisuradze \\ ${ }^{1}$ Department of Pharmacy, University of Georgia, M. Kostava str. 77a, 0171 Tbilisi, Georgia \\ 2 Institute of Inorganic-organic Hybrid Compounds and Non-traditional Materials, Iv. Javakhishvili Tbilisi State University, Chavchavadze ave. 3 , 0179 Tbilisi, Georgia \\ ${ }^{3}$ Department of Biochemistry and Microbiology, University of Chemistry and Technology, Technická 5, 16628 Praha 6-Dejvice, Czech Republic
}

\begin{abstract}
The new small peptide functionalized cyclen and DOPA derivatives were synthesized: cyclen-HisHis, cyclenAspHis, cyclen-GluHis, DOPA-HisHis were prepared. The solid-phase synthesis strategy was used for preparation of new compounds. Synthesized cyclen- and DOPA-oligopeptide hybrid conjugations were purified by HPLC and analyzed using MALDI-TOF MS spectrometer. The toxic effect was determined against mammalian cells human embryonic kidney cell line HEK293T ATCC®CLR-11268TM for each new compound. The inhibition effect of all tested cyclendipeptides on kidney cells was approximately about $30 \%$ after 24 hours. The minimal rate of toxicity against human liver cells showed all tested dipeptides with DOPA, their inhibition effect was maximal $10 \%$. The acute inhibition effect of sample DOPA-GluHis-DOPA was $14 \%$ imme $\neg$ diately after adding. The antioxidant and anticancer activity studies will be next part of the ongoing project.
\end{abstract}

Keywords: Cyclen; L-DOPA; Peptides; Solid-phase synthesis; In vitro cyctotoxicity

\section{Introduction}

Macrocyclic polyamines are widely used in biology and medicine. The new methodologies for their selective functionalization are demanding due to their importance for a variety of diagnostic and therapeutic pharmaceuticals $[1,2]$ and in the development of new MRI (Magnetic Resonance Imaging) contrast agents [3,4]. Recently, cyclenbased bifunctional chelators have attracted much interest in cancer therapy [5]. On the other hand, L-DOPA (3,4-dihydroxyphanylalanine) derivatives play a crucial role in the therapy of Parkinson disease (PD) as they increase the $\mathrm{BBB}$ penetration capacity of DOPA, which is well known medicine in the treatment of PD since 1960s. The DOPA peptidomimetics with amino acid cross-linked via oxygen atom were prepared and their antioxidant activities were studied [6].

In order to mimic biochemical processes, a number of artificial receptor molecules have been synthesized for many biologically vital molecules and enzymes. It is well known, that in such receptors, hydrogen bonding, hydrophobic or electrostatic interactions play significant role, as complementary features of the host-guest molecules. The Zinc- macrocyclic polyamine mode complexes with [12]aneN3 (cyclam) and [12]aneN4 (cyclen) showed the strong nucleophile $\mathrm{Zn}^{\mathrm{II}}-$ $\mathrm{OH}^{-}$is forms at physiological $\mathrm{pH}$ from $\mathrm{Zn}^{\mathrm{II}}-\mathrm{H}_{2} \mathrm{O}$ species [7] and logk value (6.4) indicates that $\mathrm{OH}^{-}$group is weakly bound to the metal ion and thus, can attack to $\mathrm{CO}_{2}$ or carboesters. By complexation of $\mathrm{Zn}^{\mathrm{II}}$ with [12] aneN3 (cyclam) and [12]aneN4 (cyclen) the pKa is lowering from $9.0\left(\mathrm{Zn}^{\mathrm{II}}-\mathrm{H}_{2} \mathrm{O}\right)$ to 7.3 and 7.9 , respectively, at $25^{\circ} \mathrm{C}$.

The modification of macrocyclic polyamine receptor molecules with additional ligands (arms) enables to interact with nucleobase, sugar and other biomolecules moieties for a more efficient "multipoint" recognition, as well as for thermodynamic stabilization of the ternary complexes in aqueous solution [8]. Cyclen derivatives showed antibacterial [9], anti-HIV and anti-malarial activities [10,11], zinc(II)-cyclen-peptide hybrid compounds as potential inhibitor for Ras-Ras interactions [12], as well as, macrocyclic polyamines, their derivatives, and metal complexes as potential therapeutic agents in Alzheimer's disease treatment, were reported [13-16]. The most advantage of the macrocyclic polyamines is their unique capacity to bind some biologically important metals $(\mathrm{Zn}, \mathrm{Cu}, \mathrm{Co}, \mathrm{Fe})$ and their role was dramatically increased as behavior models for enzymes and other metalloproteins. On the other hand, it is important, to inhibit proteinprotein interactions by small molecules, which are considered to be bior multivalent ligands leading to increase binding affinities providing additional binding sites [12]. In addition, $\mathrm{Zn}^{2+}$ and $\mathrm{Cu}^{2+}$ chelators are proposed as potential therapeutic agents for $\mathrm{AD}$ where redox reactions of metal-A $\beta$ aggregates can be inhibited by chelators [17]. Recently, derivatives of 1,1'-xylyl-bis-1,4,8,11-tetraazacyclododecane have been shown to be effective in reducing copper concentration and to maintain copper normal levels in rats [13]. On the other hand, macrocyclic polyamines such as cyclen and cyclam and their derivatives, as well as their metal complexes have wide applications in medicine [14,15] It is important that toxicity of cyclen and cyclam is very low $[18,19]$. The detail investigation of these macrocyclic amines on the effect of metal-induced aggregation was carried out [20] and the chelators showed ability to increase solubility of large aggregates and prevented the formation of the $\beta$-sheet structure, as well as they inhibit hydrogen peroxide $\left(\mathrm{H}_{2} \mathrm{O}_{2}\right)$ production by $\mathrm{Cu}-\mathrm{A} \beta 40$ and therefore cyclen and cyclam as proposed as good candidates to cross blood-brain barrier and with low toxicity as potential neuroprotective or neurorescue agents in the treatment of Alzheimer's disease.

Polyphenolic compounds, like coumarins and its derivatives are able to bind transition metal ions and inhibit hydroxyl radical and hydrogen peroxide formation produced by Fenton's reactions [21] and by this way, potent reactive oxygen species (ROS) scavengers and metal chelators [21]. Polyphenol derivatives (or metabolites) found numerous therapeutic applications, such as central nervous system stimulants [22],

*Corresponding author: L Arabuli, Department of Pharmacy, University of Georgia, M. Kostava str. 77a, 0171 Tbilisi, Georgia; Tel: +995591046800, E-mail: l.arabuli@ug.edu.ge

Received December 18, 2017; Accepted December 20, 2017; Published December 27, 2017

Citation: Arabuli L, Jezek R, Macek T, Lovecka P, Nikoleishvili E, et al. (2017) Solid-Phase Synthesis and In Vitro Cytotoxicity of New Peptide Functionalized Cyclencarboxymethylen and L-DOPA Hybrids. Med Chem (Los Angeles) 7: 398405. doi: 10.4172/2161-0444.1000487

Copyright: $\odot 2017$ Arabuli L, et al. This is an open-access article distributed unde the terms of the Creative Commons Attribution License, which permits unrestricted use, distribution, and reproduction in any medium, provided the original author and source are credited. 
Citation: Arabuli L, Jezek R, Macek T, Lovecka P, Nikoleishvili E, et al. (2017) Solid-Phase Synthesis and In Vitro Cytotoxicity of New Peptide Functionalized Cyclencarboxymethylen and L-DOPA Hybrids. Med Chem (Los Angeles) 7: 398-405. doi: 10.4172/2161-0444.1000487

antitumor and anti-HIV therapy [23], antibacterial [24], anticoagulants [25] etc. By-phenolic compound, such as 6,7-hydroxycoumarin, with two hydroxyl moieties prevent formation and scavenging of ROS and influence radical-mediated oxidative damage, are considered as one of the most effective antioxidant compounds and used as an protectors against DNA damage, cancer and aging [26,27].

\section{Materials and Methods}

\section{General}

2-chlorotritylchloride resin, N,N'-diisopropylcarbodiimide (DIC), piperidine (PIP) and Fmoc-protected amino acids: Fmoc-His(trt)-OH, Fmoc-Asp $(\mathrm{tBu})-\mathrm{OH}$, Fmoc-Glu(tBu)-OH were purchased from Iris Biotech GmbH (Marktredwitz, DE); triisopropylsilane (TIS) was from Novabiochem (Darmstadt, DE); N,N-diisopropylethylamine (DIEA) was obtained from Merck (Darmstadt, DE); 1-hydroxybenzotriazole (HOBt), 1,4,7,10-tetraazacyclododecane (cyclen), 1,4,7-tri-Boc-10(carboxymethyl)-tetraazacyclododecane (3N-Boc-cyclen), A $\beta$ (1-40), zinc chloride (anhydrous, $\mathrm{ZnCl}_{2}$ ) and copper sulphate pentahydrate $\left(\mathrm{CuSO}_{4}\right)$ were purchased from Sigma-Aldrich (St. Louis, MO, USA); $\mathrm{A} \beta$ (1-16), and Fmoc-DOPA(acetonide)-OH were obtained from Bachem (Bubendorf, Switzerland). High performance liquid chromatography (HPLC) grade acetonitrile (ACN), isopropyl alcohol (IPA) and dimethylformamide (DMF) were from Lachner (Neratovice, CZE); All other chemicals were of analytical or reagent grade.

\section{Purification and identification}

After the synthesis, the crude products (dipeptides, cyclendipeptides, DOPA-dipeptides, DOPA-dipeptide-DOPA and cyclenDOPA) were purified by RP-HPLC using a $100 \mathrm{~min}(3 \mathrm{ml} / \mathrm{min}$ ) gradient from 0 to $100 \%$ ACN. For identification of synthesized compounds were analyzed by MALDI-TOFMS spectrometer.

\section{Experimental part}

Solid-phase synthesis of cyclen/DOPA-peptides: All peptide conjugations were synthesized manually by a stepwise strategy. The general procedure for each synthetic cycle, based on initial resin, was as follows:

(1) attachment of Fmoc-His(Trt)-OH or Fmoc-DOPA(ac)-OH (Figure 1) on 2-chlorotrityl resin $(\mathrm{S}=1.55 \mathrm{mM} / \mathrm{g})$, washings: DMF, i-PrOH, DMF, each 3x1 min; (2) Deprotection-20\% PIP in DMF for 30 min; washings: DMF, i-PrOH, DMF, each 3x1 min; (3) Coupling: HOBt 5 eq in DMF, coupling reagent (Fmoc-AA, 3N-Boc-Cyclen$\mathrm{CH}_{2} \mathrm{COOH}$, Fmoc-DOPA(ac)-OH), 4 eq in DMF; 2M DIC/DMF, 7 eq;
Bromophenol blue (BB, 0,1\% in DMF)-26-31 $\mu \mathrm{L}$; shaking the syringes at r.t. for at least $5 \mathrm{~h}$, the reaction time was corrected depending upon the indicator (BB) color change in yellow; (4) washings: $\mathrm{DMF}, \mathrm{i}-\mathrm{PrOH}$, DMF, each $3 \times 1 \mathrm{~min}$; (5) Cleavage of synthesized compounds from the resin and deprotection of side chains were performed in solution of 95\% TFA, 2.5\% TIS and 2.5\% $\mathrm{H}_{2} \mathrm{O}$, the reaction time was $3.5 \mathrm{~h}$ followed by 3-4 TFA washing; TFA was removed with the stream of nitrogen. The products were precipitated with tert-BuOMe and (Et) ${ }_{2} \mathrm{O}$ ethers and collected by centrifugation $(2000 \mathrm{xg}, 2 \mathrm{~min})$.

Cyclen-HisHis-OH: 3N-Boc-cyclen-55 mg (102 $\mu \mathrm{M}$, 1.0 eq) in 200 $\mu \mathrm{L}$, His(Trt)-His(Trt)- ${ }^{-}-382 \mathrm{mg}(204 \mu \mathrm{M}, 1.0 \mathrm{eq})$, HOBt-29.0 mg (214 $\mu \mathrm{M}, 2.1 \mathrm{eq})$ in $50 \mu \mathrm{L}$ DMF, BB- $26 \mu \mathrm{L}$, DIC-153 $\mu \mathrm{L}$ (306 $\mu \mathrm{M}, 3.0$ eq) in $50 \mu \mathrm{L}$ DMF. Yield: crude-105.0 mg (87.2\%), pure-54.1 mg (44.8\%); MS $\left(\mathrm{M}+\mathrm{H}^{+}\right) 501$.

Cyclen-AspHis-OH: 3N-Boc-cyclen-55 mg (102 $\mu \mathrm{M}, 1.0$ eq) in 200 $\mu \mathrm{L}, \operatorname{Asp}(\mathrm{O}-\mathrm{tBu})-\mathrm{His}(\mathrm{Trt}){ }^{-}-277 \mathrm{mg}(208 \mu \mathrm{M}, 1.0 \mathrm{eq})$, HOBt-30.0 mg $(218 \mu \mathrm{M}, 2.1 \mathrm{eq})$ in $50 \mu \mathrm{L}$ DMF, BB-27 $\mu \mathrm{L}, \mathrm{DIC}-156 \mu \mathrm{L}(312 \mu \mathrm{M}, 3.0 \mathrm{eq})$ in $50 \mu \mathrm{L}$ DMF. Yield: crude-88.0 mg (79.3\%), pure-69.0 $\mathrm{mg}(62.2 \%)$; MS $\left(\mathrm{M}+\mathrm{H}^{+}\right) 482.95$.

Cyclen-GluHis-OH: 3N-Boc-cyclen-55 mg (102 $\mu \mathrm{M}, 1.0 \mathrm{eq})$ in $200 \mu \mathrm{L}, \mathrm{Glu}(\mathrm{O}-\mathrm{tBu})-\mathrm{His}(\mathrm{Trt}){ }^{-}{ }^{-}-387 \mathrm{mg}(204 \mu \mathrm{M}, 1.0 \mathrm{eq})$, HOBt-29.0 $\mathrm{mg}(214 \mu \mathrm{M}, 2.1 \mathrm{eq})$ in $50 \mu \mathrm{L} \mathrm{DMF}, \mathrm{BB}-27 \mu \mathrm{L}$, DIC-153 $\mu \mathrm{L}(306 \mu \mathrm{M}$, 3.0 eq) in $50 \mu \mathrm{L}$ DMF. Yield: crude- $106.0 \mathrm{mg}$ (87.4\%), pure-59.4 mg (49.1\%); MS $\left(\mathrm{M}+\mathrm{H}^{+}\right) 497$.

DOPA-HisHis-OH: His(Trt)-His(Trt)- ${ }^{\circledR}-470 \mathrm{mg}(250 \mu \mathrm{M}, 1.0 \mathrm{eq})$, Fmoc-DOPA(ac)-OH-150 mg (326 $\mu \mathrm{M}, 1.3 \mathrm{eq})$ in $450 \mu \mathrm{L}$ DMF, HOBt$51.0 \mathrm{mg}(375 \mu \mathrm{M}, 1.5 \mathrm{eq})$ in $300 \mu \mathrm{L}$ DMF, BB-32 $\mu \mathrm{L}$, DIC-288 $\mu \mathrm{L}(575$ $\mu \mathrm{M}, 2.3$ eq). Yield: crude-117.0 mg (86.5\%), pure-76.0 mg (56.2\%); MS $\left(\mathrm{M}+\mathrm{H}^{+}\right)$471.49.

DOPA-AspHis-OH: Asp(O-tBu)-His(Trt)- ${ }^{-}-332 \mathrm{mg}(250 \mu \mathrm{M}, 1.0$ eq), Fmoc-DOPA(ac)-OH-150 mg $(326 \mu \mathrm{M}, 1.3 \mathrm{eq})$ in $450 \mu \mathrm{L} \mathrm{DMF}$, HOBt-51.0 mg ( $375 \mu \mathrm{M}, 1.5 \mathrm{eq})$ in $250 \mu \mathrm{L}$ DMF, BB-32 $\mu \mathrm{L}$, DIC- $288 \mu \mathrm{L}$ (575 $\mu \mathrm{M}, 2.3$ eq). Yield: crude-112.0 mg (84.1\%), pure-80.6 mg (60.5\%); MS $\left(\mathrm{M}+\mathrm{H}^{+}\right) 449.49$.

DOPA-GluHis-OH: Glu(O-tBu)-His(Trt)- ${ }^{-}-474 \mathrm{mg}(250 \mu \mathrm{M}, 1.0$ eq), Fmoc-DOPA(ac)-OH-150 mg (326 $\mu \mathrm{M}, 1.3 \mathrm{eq})$ in $450 \mu \mathrm{L}$ DMF, HOBt-51.0 mg ( $375 \mu \mathrm{M}, 1.5$ eq) in $250 \mu \mathrm{L}$ DMF, BB-32 $\mu \mathrm{L}$, DIC- $288 \mu \mathrm{L}$ (575 $\mu \mathrm{M}, 2.3 \mathrm{eq})$. Yield: crude-107.0 mg (79.2\%), pure-60.8 mg (45.0\%); MS $\left(\mathrm{M}+\mathrm{H}^{+}\right) 463.49$.

Cyclen-DOPA: 3N-Boc-cyclen-335 mg $(631 \mu \mathrm{M}, 1.1 \mathrm{eq})$ in $1.0 \mathrm{~mL}$ DMF, DOPA(ac)- ${ }^{\circ}-800$ mg (576 $\mu \mathrm{M}, 1.0$ eq), HOBt-156.0 mg (1152
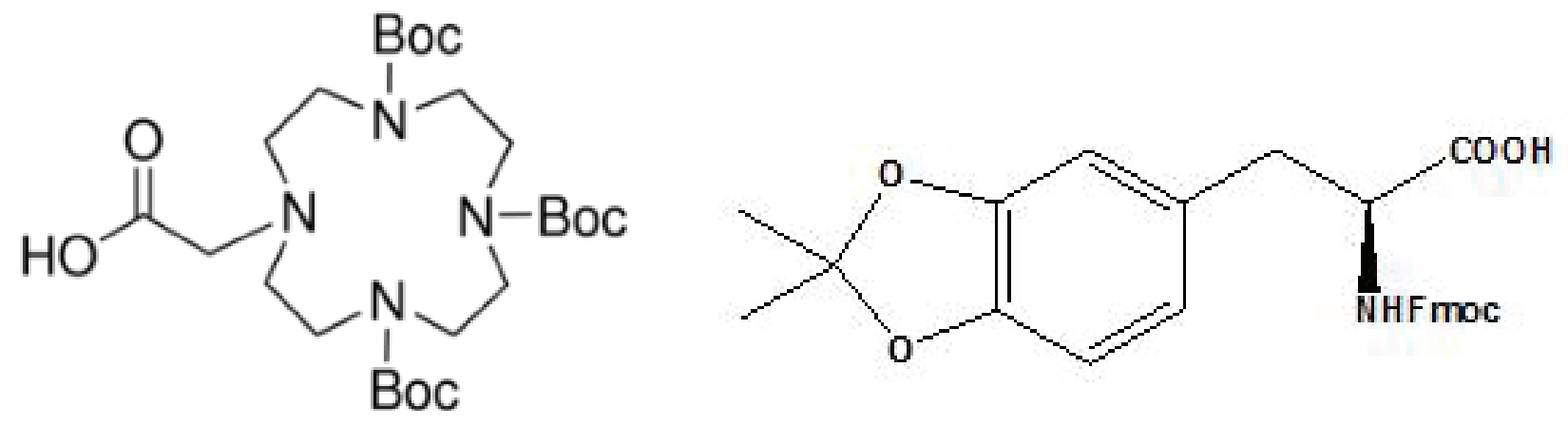

Figure 1: Substrates: $3 \mathrm{~N}$-cyclen- $\mathrm{CH}_{2} \mathrm{COOH}$ and Fmoc-DOPA(ac)-OH. 
Citation: Arabuli L, Jezek R, Macek T, Lovecka P, Nikoleishvili E, et al. (2017) Solid-Phase Synthesis and In Vitro Cytotoxicity of New Peptide Functionalized Cyclencarboxymethylen and L-DOPA Hybrids. Med Chem (Los Angeles) 7: 398-405. doi: 10.4172/2161-0444.1000487

$\mu \mathrm{M}, 2.1 \mathrm{eq})$ in $250 \mu \mathrm{L}$ DMF, BB-74 $\mu \mathrm{L}$, DIC-864 $\mu \mathrm{L}(1728 \mu \mathrm{M}, 3.0$ eq). Yield: crude-291.0 mg (90.1\%), pure-201.0 mg (62.2\%); MS $\left(\mathrm{M}+\mathrm{H}^{+}\right)$ 409.49.

DOPA-HisHis-DOPA: Fmoc-His(Trt)-OH-303 mg $(490 \mu \mathrm{M}, 2.0$ eq) in $650 \mu \mathrm{L}$ DMF, DOPA(ac)- ${ }^{-}-340 \mathrm{mg}(245 \mu \mathrm{M}, 1.0 \mathrm{eq})$, HOBt-83.0 $\mathrm{mg}(612.5 \mu \mathrm{M}, 2.5 \mathrm{eq})$ in $120 \mu \mathrm{L}$ DMF, BB-31 $\mu \mathrm{L}$, DIC-429 $\mu \mathrm{L}(858 \mu \mathrm{M}$, 3.5 eq). Coupling with another His: Fmoc-His(Trt)-OH-380 mg (613 $\mu \mathrm{M}, 2.5 \mathrm{eq})$ in $800 \mu \mathrm{L}$ DMF, HOBt-102.0 $\mathrm{mg}(760 \mu \mathrm{M}, 3.1 \mathrm{eq})$ in 180 $\mu \mathrm{L}$ DMF, BB-31 $\mu \mathrm{L}$, DIC-536 $\mu \mathrm{L}(1072 \mu \mathrm{M}, 4.38$ eq). Coupling with another DOPA: Fmoc-DOPA(ac)-OH-123 mg $(270 \mu \mathrm{M}, 1.1 \mathrm{eq})$ in 150 $\mu \mathrm{L}$ DMF, HOBt-66.0 mg $(490 \mu \mathrm{M}, 2.0$ eq $)$ in $300 \mu \mathrm{L}$ DMF, BB-31 $\mu \mathrm{L}$, DIC-370 $\mu \mathrm{L}$ (735 $\mu \mathrm{M}, 3.0$ eq). Yield: crude-215.1 mg (80.3\%), pure$190.2 \mathrm{mg}(70.9 \%) ; \mathrm{MS}\left(\mathrm{M}+\mathrm{H}^{+}\right) 650.38$.

DOPA-AspHis-DOPA: Fmoc-His(Trt)-OH-303 mg $(490 \mu \mathrm{M}, 2.0$ eq) in $650 \mu \mathrm{L}$ DMF, DOPA(ac)- ${ }^{-}-340 \mathrm{mg}(245 \mu \mathrm{M}, 1.0 \mathrm{eq})$, HOBt-83.0 $\mathrm{mg}(612.5 \mu \mathrm{M}, 2.5 \mathrm{eq})$ in $120 \mu \mathrm{L} \mathrm{DMF}, \mathrm{BB}-31 \mu \mathrm{L}$, DIC- $429 \mu \mathrm{L}(858$ $\mu \mathrm{M}, 3.5 \mathrm{eq})$. Coupling with Asp: Fmoc-Asp(O-tBu)-OH-252 mg (613 $\mu \mathrm{M}, 2.5 \mathrm{eq})$ in $800 \mu \mathrm{L}$ DMF, HOBt-102.0 $\mathrm{mg}(760 \mu \mathrm{M}, 3.1 \mathrm{eq})$ in 180 $\mu \mathrm{L}$ DMF, BB-31 $\mu \mathrm{L}$, DIC-536 $\mu \mathrm{L}(1072 \mu \mathrm{M}, 4.38$ eq). Coupling with another DOPA: Fmoc-DOPA(ac)-OH-123 mg $(270 \mu \mathrm{M}, 1.1 \mathrm{eq})$ in 150 $\mu \mathrm{L}$ DMF, HOBt-66.0 mg (490 $\mu \mathrm{M}, 2.0 \mathrm{eq})$ in $300 \mu \mathrm{L} \mathrm{DMF}, \mathrm{BB}-31 \mu \mathrm{L}$, DIC-370 $\mu \mathrm{L}(735 \mu \mathrm{M}, 3.0$ eq). Yield: crude- $247.0 \mathrm{mg}$ (85.6\%), pure$203.1 \mathrm{mg}(70.4 \%) ; \mathrm{MS}\left(\mathrm{M}+\mathrm{H}^{+}\right) 628.38$.

DOPA-GluHis-DOPA: Fmoc-His(Trt)-OH-303 mg (490 $\mu$ M, 2.0 eq) in $650 \mu \mathrm{L}$ DMF, DOPA(ac) ${ }^{-}{ }^{-}-340 \mathrm{mg}(245 \mu \mathrm{M}, 1.0 \mathrm{eq})$, HOBt-83.0 $\mathrm{mg}(612.5 \mu \mathrm{M}, 2.5 \mathrm{eq})$ in $120 \mu \mathrm{L} \mathrm{DMF}, \mathrm{BB}-31 \mu \mathrm{L}$, DIC-429 $\mu \mathrm{L}(858$ $\mu \mathrm{M}, 3.5 \mathrm{eq})$. Coupling with Glu: Fmoc-Glu(O-tBu)-OH-261 mg (613 $\mu \mathrm{M}, 2.5 \mathrm{eq})$ in $800 \mu \mathrm{L}$ DMF, HOBt-102.0 $\mathrm{mg}(760 \mu \mathrm{M}, 3.1 \mathrm{eq})$ in 180 $\mu \mathrm{L}$ DMF, BB-31 $\mu \mathrm{L}$, DIC-536 $\mu \mathrm{L}(1072 \mu \mathrm{M}, 4.38$ eq). Coupling with another DOPA: Fmoc-DOPA(ac)-OH-123 mg (270 $\mu \mathrm{M}, 1.1 \mathrm{eq})$ in 150 $\mu \mathrm{L}$ DMF, HOBt-66.0 mg $(490 \mu \mathrm{M}, 2.0 \mathrm{eq})$ in $300 \mu \mathrm{L} \mathrm{DMF}, \mathrm{BB}-31 \mu \mathrm{L}$, DIC-370 $\mu \mathrm{L}$ (735 $\mu \mathrm{M}, 3.0$ eq). Yield: crude- $188.2 \mathrm{mg}(77.2 \%)$, pure$102.1 \mathrm{mg}(41.9 \%) ; \mathrm{MS}\left(\mathrm{M}+\mathrm{H}^{+}\right) 642.38$.

\section{Cytotoxicity Assay}

Monitoring of cell growth with the RTCA DP instrument: Experiments were carried out using the xCELLigence RTCA DP instrument (Roche Diagnostics $\mathrm{GmbH}$, Mannheim, Germany) which was placed into a incubator $\left(37^{\circ} \mathrm{C}\right.$ and $\left.5 \% \mathrm{CO}_{2}\right)$. Cell proliferation and cytotoxicity experiments were performed using modified 16-well plates (E-plate, Roche Diagnostics GmbH, Mannheim, Germany).

Microelectrodes were attached at the bottom of the wells for impedance-based detection of attachment, spreading and proliferation of the cells. Initially, $100 \mu \mathrm{L}$ of cell-free growth medium (10\% FBS, $1 \%$ MEM) was added to the wells.

Cells were harvested from exponential phase cultures by a standardized detachment procedure using $0.25 \%$ Trypsin-EDTA and counted automatically using Roche's CASY Cell Counter and Analyzer. $100 \mu \mathrm{L}$ of the cell suspension was seeded into the wells as $10^{6} \mathrm{HEK}-293 \mathrm{~T}$ cells $/ \mathrm{ml}$ for cytotoxicity experiments. Twenty-four hours after cell seeding were added tested substances dissolved in water (concentration $50 \mu \mathrm{g} / \mathrm{ml}$ ) and also during a period of 72 hours with. Water was added to control wells. CI (cell index) was monitored every $60 \mathrm{~min}$ during the experiment for 72 hours. This results into growth curves (dependence of the impedance expressed by the "cell index" value on time) of monitored cells in the presence of individual substances. HEK293T ATCC ${ }^{\circ}$ CRL- $11268^{\mathrm{TM}}$ are epithelial cells derived from kidney of human fetus. HEK-293T cells were cultivated in Dulbecco's modified
Eagle's medium (DMEM; with $4.5 \mathrm{~g} / \mathrm{L}$ glucose and L-Glutamine), supplemented with $10 \%$ fetal bovine serum (FBS) and $1 \%$ of MEM (mix of vitamines-Gibco, GB. Cells were cultured at $37^{\circ} \mathrm{C}$ and $5 \% \mathrm{CO}_{2}$; cultivation medium was changed every 2 to 3 days. For experimental procedures, cells were seeded in 96-well plates at a concentration of $10^{5}$ cells/ml per well.

\section{Results and Discussion}

The new small peptide functionalized cyclen and DOPA derivatives were synthesized: cyclen-HisHis, cyclen-AspHis, cyclen-GluHis, DOPA-HisHis, DOPA-AspHis, DOPA-GluHis, DOPA-HisHisDOPA, DOPA-AspHis-DOPA, DOPA-GluHis-DOPA and DOPAcyclen (Figure 2). The solid-phase synthesis strategy was used for preparation of new compounds. The His-rich cyclen conjugations could be serve as DNA, ATP and other biomolecules recognition models, as bifunctional molecules (protein interaction and metal chelation) in metal chelation therapy approach and polyphenolic DOPA derivatives, as metal chelators and radical scavengers. The general synthetic procedure is given on Scheme 1 and 2. We prepared the cyclencarboxymethyl derivatives withtert $\mathrm{Bu}$-and Trt-protected dipeptides, including HisHis, GluHis and AspHis, and Dopasubstituted carboxymethylencyclen. Compound 1 (Fmoc-His(Trt)$\mathrm{OH}, 4.61 \mathrm{~g}, 7.44 \mathrm{mM}, 1.2$ eq.) was dissolved in DMF and $4.21 \mathrm{~mL}(24.8$ $\mathrm{mM}, 4.0 \mathrm{eq}$ ) diisopropylethylamine (DIEA) was added to the syringe with 2-chlorotrityl chloride resin $(\mathrm{S}=1.55 \mathrm{mg} / \mathrm{g}, 4.0 \mathrm{~g}, 6.2 \mathrm{mM}, 1 \mathrm{eq})$, which was preliminary washed with THF $(3 \mathrm{x})$ and swelled in DCM $\left(\mathrm{CH}_{2} \mathrm{Cl}_{2}\right)$. The syringe was shaked for $\sim 5 \mathrm{hrs}$ at room temperature. As color turned from yellow to brown-orange, the reaction content was washed with DMF, i-PrOH, DMF (3x). The Fmoc-His(Trt)- ${ }^{\circledR}$ was dried and half of this His-attached resin was swelled for $20 \mathrm{~min}, 20 \%$ Piperidine (PIP) in DMF was added for Fmoc-deprotection for $30 \mathrm{~min}$. The another portion of Fmoc-His(Trt)- ${ }^{-}(2.73 \mathrm{~g}, 4.4 \mathrm{mM}, 2 \mathrm{eq}), \mathrm{HOBt}$ (0.74 g, $5.5 \mathrm{mM}, 2.5 \mathrm{eq}), 2 \mathrm{M}$ DIC/DMF solution $(3.85 \mathrm{~mL}, 7.7 \mathrm{~mm}, 3.5$ eq) and $0,1 \%$ bromophenol blue $(286 \mu \mathrm{L})$ were added. The reaction was shaked for overnight until color turned from bluin yellow. The Fmoc group was deprotected again 20\% PIP, washed and dried. Finally, the crude $\mathrm{H}$-His(Trt)-His- ${ }^{-}$product was deprotected with $95 \%$ THF $(2.5 \%$ TIS, $2.5 \% \mathrm{H}_{2} \mathrm{O}$ ), then acids were removed under $\mathrm{N}_{2}$ stream and product was extracted by $\mathrm{MeOBu}$ and $\mathrm{Et}_{2} \mathrm{O}$ ethers. The crude products were purified by HPLC. Solvents were removed by rotovap and lyophilized to obtain colorless crystals.

$\mathrm{N}$-functionalization of tetraazamacrocycles and their derivatives has been reported [28-30]. Generally, modification of such compounds is occurring via $n$-derivatization by a) derivatization and b) protectionderivatization-deprotection [28-30]. Synthesis of tetraazamacrocycleKLVFF hybrids-the amide-or triazole linked derivatives and their metal complexes were reported [31] using Fmoc-strategy solid phase synthesis on Wang resin and subsequent coupling with tri-Boctetraazamacrocycle-acetic acid. These hybrid compounds showed neuroprotective effects of Ab in Alzheimer's disease. The cyclen and cyclam were attached to the synthetic pentapeptide-KLVFF, a short Ab fragment (Ab16-20) which was chosen for amyloidic recognition and disruption of aggregates into fibrils $[32,33]$. The glycine and triazole spacers were additionally incorporated in tetraazamacrocycle hybrids. On the other hand, dopamine precursors, such as levodopa (L-Dopa) or dopaminergic compounds are generally used for the treatment of Parkinson's disease $[34,35]$. Parkinson's disease treatment efforts are concerned to the improvement of BBB permeability of candidate molecules, and thus, brain delivery $[36,37]$. With this aim, L-dopa dipeptide derivatives using non-natural amino acids were prepared and 
<smiles>CCCCCCCCCCCCC(=O)NC(Cc1c[nH]cn1)C(=O)NC(Cc1ccc(O)c(O)c1)C(=O)O</smiles>

DOPA-Asp-His<smiles>CC(C)NC(=O)CN(CCNCCNCCNCCNCCc1ccc(O)c(O)c1)C(=O)O</smiles>

Cyclen-DOPA<smiles>O=C(O)CCC(NC(=O)CN1CCNCCNCCNCC1)C(=O)NC(Cc1c[nH]cn1)C(=O)O</smiles>

Cyclen-Glu-His<smiles>O=C(CN1CCNCCNCCNCC1)NC(Cc1c[nH]cn1)C(=O)NC(Cc1c[nH]cn1)C(=O)O</smiles>

Cyclen-His-His<smiles>NC(Cc1ccc(O)c(O)c1)C(=O)NC(Cc1c[nH]cn1)C(=O)NC(Cc1c[nH]cn1)C(=O)O</smiles>

DOPA-His-His<smiles>NC(Cc1ccc(O)c(O)c1)C(=O)NC(CCC(=O)O)C(=O)NC(Cc1c[nH]cn1)C(=O)O</smiles>

DOPA-Glu-His<smiles>O=C(O)CC(NC(=O)CN1CCNCCNCCNCC1)C(=O)NC(Cc1c[nH]cn1)C(=O)O</smiles>

Cyclen-Asp-His<smiles>Cc1ccc(CC(N)C(=O)NC(C)C(=O)NC(Cc2cnc[nH]2)C(=O)NC(Cc2ccc(O)c(O)c2)C(=O)O)cc1O</smiles>

DOPA-AA-His-DOPA

Figure 2: Structures of dipeptide derivatives of carboxymethylcyclen, DOPA and DOPA-cyclen hybrids.

their antiparkinsonic activity was studied [38] and amide derivatives of L-Dopa [39], from which the higher promising prodrug was diacetyl derivative of the simple L-Dopa amide.

The new compounds were derived with good yield. Possible cytotoxicity of new biological active peptides to mammalian cells is another disadvantage in their potential clinical use. Testing of the biological properties of peptides includes the determination of cytotoxic activity to the basic test parameters. To measure cytotoxicity, a system was used to assess the viability of adhering cells based on their degree of adhesion to the bottom of the microtiter plate, or a decrease in resistance between the surface of the electrodes and the culture medium. Next we investigated the toxic effect against mammalian cells human embryonic kidney cell line HEK293T ATCC ${ }^{\circ}$ CLR-11268TM with each peptide. Toxic activity was determined in concentration 50 $\mu \mathrm{g} / \mathrm{ml}$. Figure 3 shows proliferation curves of cell line HEK 293T after adding group of cyclens of different dipeptides. The inhibition effect of 
<smiles>CCn1cnc(CC(NCPC(=O)OCc2ccccc2)C(=O)OCc2ccccc2)c1</smiles>

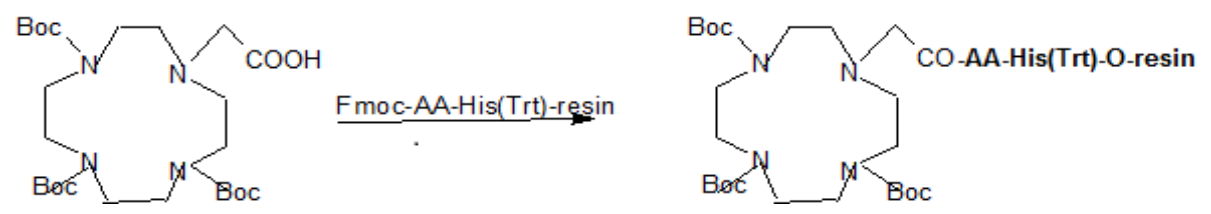

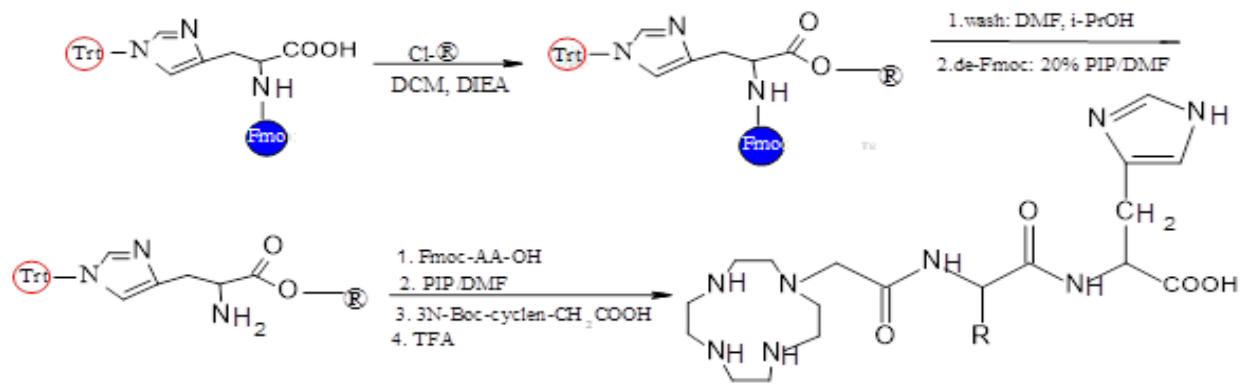<smiles>COc1ccc(C(O)(c2ccccc2)c2ccccc2)cc1</smiles>

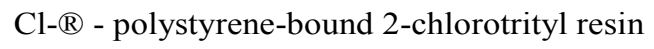

Scheme 1: Stepwise reaction of functional derivation of tri-N-Boc-Cyclen- $\mathrm{CH}_{2} \mathrm{COOH}$ with dipeptide $(\mathrm{HH}, \mathrm{DH}, \mathrm{EH})$.

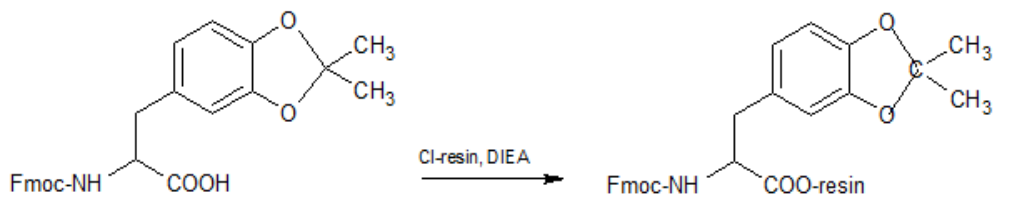<smiles>[R]C(NC(=O)C(N)Cc1ccc(O)c(O)c1)C(=O)NC(Cc1c[nH]cn1)C(=O)NC(Cc1ccc(O)c(O)c1)C(=O)O</smiles>

Scheme 2: Stepwise reaction of modification of Fmoc-DOPA(ac)-OH with dipeptides. 
Citation: Arabuli L, Jezek R, Macek T, Lovecka P, Nikoleishvili E, et al. (2017) Solid-Phase Synthesis and In Vitro Cytotoxicity of New Peptide Functionalized Cyclencarboxymethylen and L-DOPA Hybrids. Med Chem (Los Angeles) 7: 398-405. doi: 10.4172/2161-0444.1000487

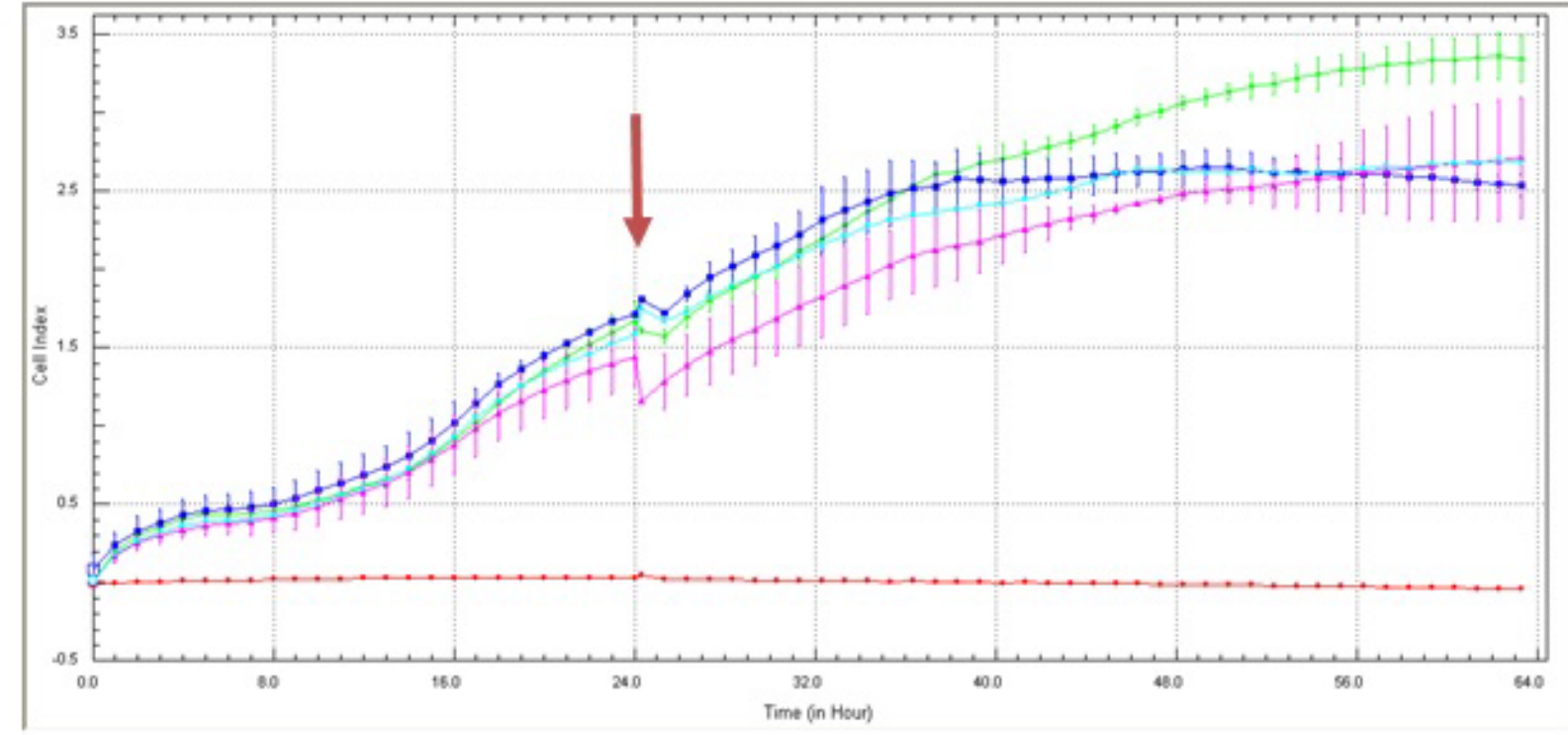

Cell line HEK 293 T (concentration of cell $10^{6} \mathrm{cell} / \mathrm{ml}$ ) Concentration of samples $50 \mu \mathrm{g} / \mathrm{ml}$

Figure 3: Proliferation curves of cell line HEK 293T (concentration of cell 10\%/ml) after adding tested samples (green-control, blue-cyclen-HisHis, pink-cyclenGluHis, turquoise- cyclen-AspHis; red arrow-sample added.

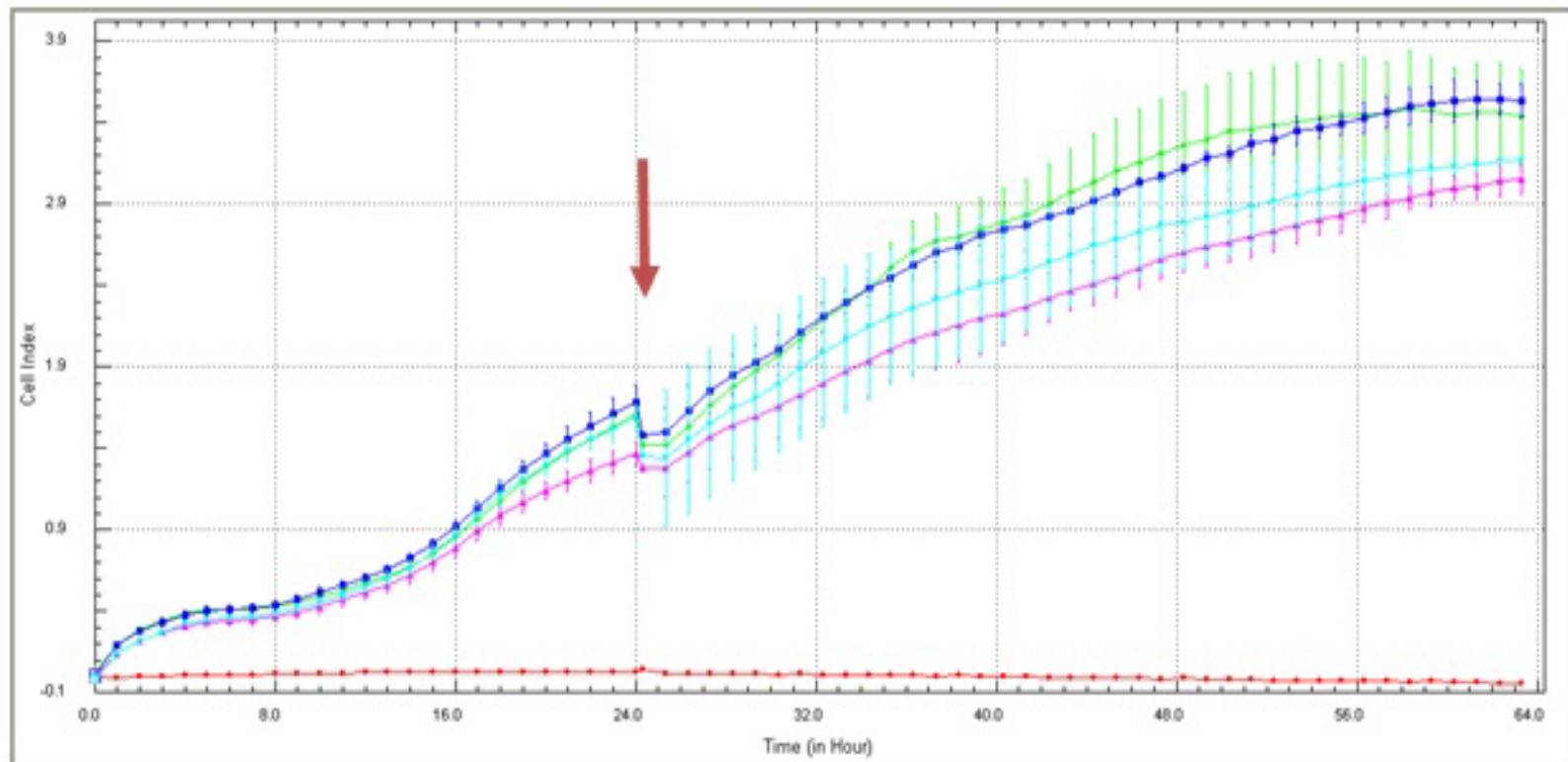

Figure 4: Proliferation curves of cell line HEK 293 T (concentration of cell 10\%/ml) after adding tested samples (green-control, blue-DOPA-HisHis, pink-DOPAGluHis, turquoise-DOPA-AspHis; red arrow-sample added.

all tested cyclen-dipeptides on kidney cells was approximately about $30 \%$ after 24 hours. The minimal rate of toxicity against human liver cells showed all tested dipeptides with DOPA, their inhibition effect was maximal $10 \%$ (Figure 4). The acute inhibition effect of sample DOPA-GluHis-DOPA was 14\% immediately after adding (Figure 5).

The obtained results showed that further analyses and testing will be followed, such as anticancer and antioxidant activities, interaction with aggregated amyloid beta peptide and toxicity on neuronal cells will be observed in vitro.

\section{Conclusion}

The new small peptide functionalized cyclen and DOPA derivatives - cyclen-HisHis, cyclen-AspHis, cyclen-GluHis, cyclen-DOPA, DOPA-HisHis, DOPA-AspHis, DOPA-Glu-His, DOPA-HisHisDOPA, DOPA-AspHis-DOPA and DOPA-Glu-His-DOPA were prepared. The solid-phase synthesis strategy was used for preparation of new compounds. Synthesized cyclen- and DOPA-oligopeptide hybrid conjugations were purified by RP-HPLC and analyzed using MALDI TOF MS spectrometer. The toxic effect was determined 
Citation: Arabuli L, Jezek R, Macek T, Lovecka P, Nikoleishvili E, et al. (2017) Solid-Phase Synthesis and In Vitro Cytotoxicity of New Peptide Functionalized Cyclencarboxymethylen and L-DOPA Hybrids. Med Chem (Los Angeles) 7: 398-405. doi: 10.4172/2161-0444.1000487

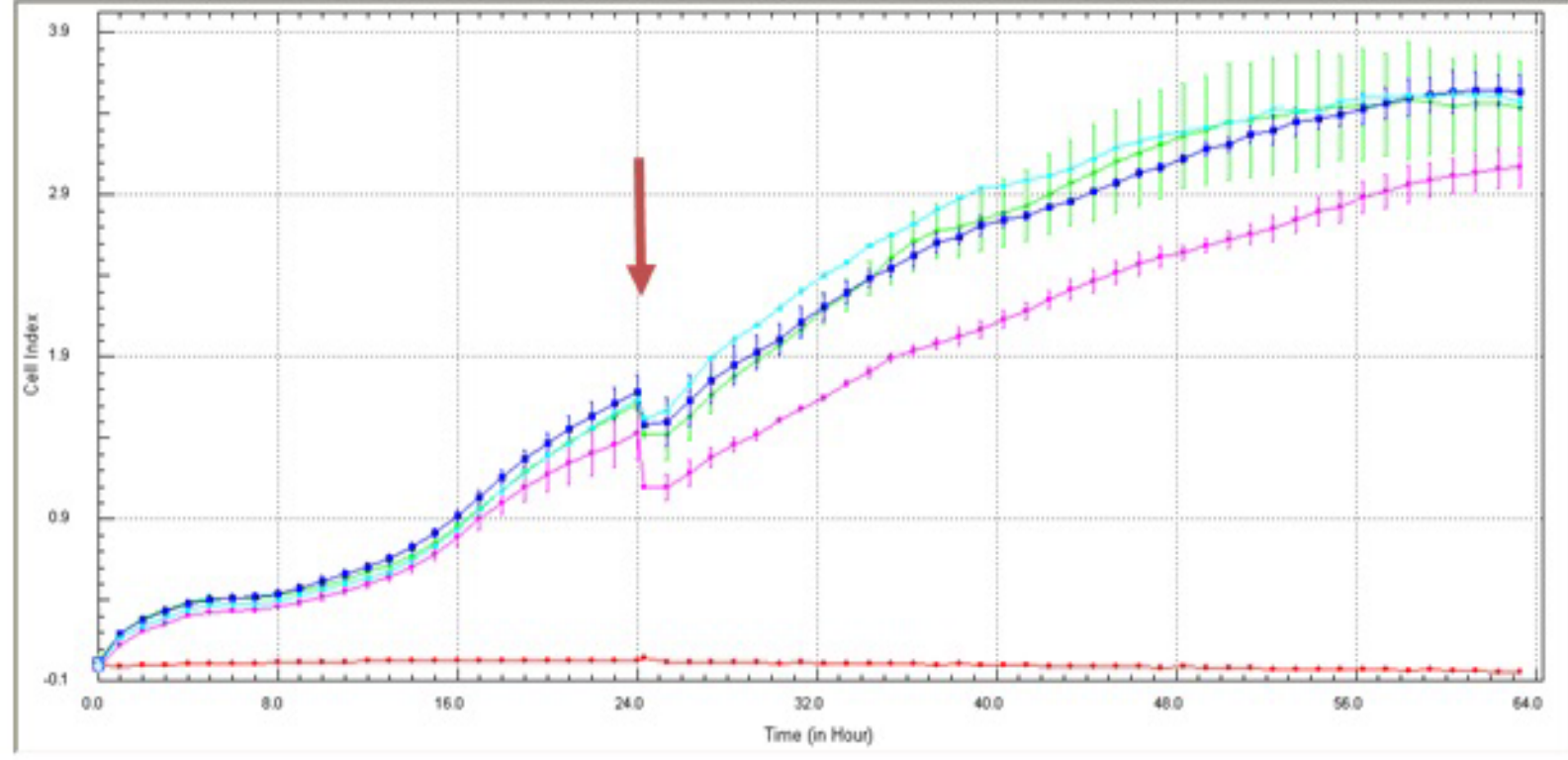

Figure 5: Proliferation curves of cell line HEK 293T (concentration of cell 10\%/ml) after adding tested samples (green-control, blue-DOPA-HisHis-DOPA, pinkDOPA-GluHis-DOPA, turquoise-DOPA-AspHis-DOPA; red arrow-sample added).

against mammalian cells human embryonic kidney cell line HEK293T ATCC ${ }^{\circ}$ CLR-11268TM for each new compound. Toxic activity was determined in concentration $50 \mu \mathrm{g} / \mathrm{ml}$. The inhibition effect of all tested cyclen-dipeptides on kidney cells was approximately about $30 \%$ after 24 hours. The minimal rate of toxicity against human liver cells showed all tested dipeptides with DOPA, their inhibition effect was maximal $10 \%$. The acute inhibition effect of sample DOPA-GluHis-DOPA was $14 \%$ immediately after adding. Their antioxidant and anticancer activities will be studied based on the obtained toxicity results.

\section{Acknowledgement}

The financial support from the Visegrad International Fund and an internal grant of the University of Georgia (school of health sciences and public health) are gratefully acknowledged.

\section{References}

1. Aoki S, Kimura E (2004) Zinc-nucleic acid interaction. Chem Rev 104: 769-788.

2. Bradshaw JS, Krakowiak KE, Izatt RM (1993) The chemistry of heterocyclic compounds, Wilay and Sons, Inc: 16-21, 83-85, 157-165.

3. Caravan PJ, Ellison J, McMurray TJ, Lauffer RB (1999) Gadolinium(III) Chelates as MRI Contrast Agents: Structure, Dynamics, and Applications. Chem Rev 99: 2293-2352.

4. Cakic N, Gunduz S, Rengarasu R, Angelovski G (2015) Synthetic strategies for preparation of cyclen-based MRI contrast agents. Tetrahedron Letters 56: 759-765

5. Liu S, Edwards DS (2001) Bifunctional chelators for therapeutic lanthanide radiopharmaceuticals. Bioconj Chem 12: 7-34.

6. Mattia Bazzarri B, Pieri C, Botta G, Arabuli L, Mosesso P, et al. (2015) Synthesis and antioxidant activity of DOPA peptidomimetics by a novel IBX mediated aromatic oxidative functionalization. RSC Advances 5: 60354-60364.

7. Kimura E, Shiota T, Koike T, Shiro M, Kodama M (1990) A zinc(II) complex of 1,5,9-triazacyclododecane ([12]aneN3) as a model for carbonic anhydrase. J Am Chem Soc 112: 5805-5811.

8. Kimura E, Shionoya M (1994) Macrocyclic polyamine complex beyond metalloenzyme models. In: Transition metals in supramolecular chemistry. Kluwar Academic Publishers: 245-259.

9. Chen Q, Ma Z, Liu G, Wei H, Xie X (2016) Antibacterial activity of cationic cyclen-functionalized fullerene derivatives: membrane stress. Digest Journal of Nanomaterials and Biostructures 11: 753-761.

10. Khan MOF, Levi MS, Tekwani BL, Khan SI, Kimura E, et al. (2009) Synthesis and Antimalarial Activities of Cyclen 4-Aminoquinoline Analogs. Antimicrobial Agents and Chemotherapy 53: 1320-1324.

11. Amoyaw PN, Pham K, Cain AN, McClain JM, Hubin TJ, et al. (2014) Synthesis of Novel Tetraazamacrocyclic Bisquinoline Derivatives as Potential Antimalarial Agents. Current Org Synthesis 11: 916-921.

12. Schmidt F, Rosnizeck IC, Spoerner M, Kalbitzer HR, König B (2001) Zinc(II) cyclen-peptide conjugates interacting with the weak effector binding state of Ras. Inorg Chim Acta 365: 38-48.

13. Moret V, Laras Y, Pietrancosta N, Garino C, Quelever G, et al. (2006) 1, 1'-Xylyl bis-1, 4, 8, 11-tetraaza cyclotetradecane: a new potential copper chelator agent for neuroprotection in Alzheimer's disease. Bioorg Med Chem Lett 16: 32983301.

14. Liang XY, Sadler PJ (2004) Cyclam complexes and their applications in medicine. Chem Soc Rev 33: 246-266.

15. Delgado R, Felix V, Lima LM, Price DW (2007) Metal complexes of cyclen and cyclam derivatives useful for medical applications: a discussion based on thermodynamic stability constants and structural data. Dalton Trans 26: 2734 2745.

16. Chen T, Wang X, He Y, Zhang Ch, Wu Z, et al. (2009) Effects of cyclen and cyclam on zinc(II)- and copper(II)-induced amyloid $\beta$-peptide aggregation and neurotoxicity. Inorg Chem 48: 5801-5809.

17. Daraeva C, Pitic M, Meunier B (2006) Influence of chelators and iron ions on the production and degradation of $\mathrm{H}_{2} \mathrm{O}_{2}$ by beta-amyloid-copper complexes. $J$ Inorg Biochem 100: 2117-2126.

18. Pilichowski JF, Michelot J, Borel M, Meyniel G (1983) Enhanced elimination of $64 \mathrm{Cu}$ in rats by cyclen, a macrocyclic polyamine. Naturwissenschaften 70 201-202.

19. Srivastava A, Katiyar SS, Behari JR, Hasan SK, Srivastava SK, et al. (1988) Evaluation of LD50 of some macrocyclic drugs and their linear analogues used as chelating drugs in metal intoxication. Chemosphere 17: 839-844.

20. Chen T, Wang X, He Y, Zhang Ch, Wu Z, et al. (2009) Effects of cyclen and cyclam on zinc(II)- and copper(II)-induced amyloid $\beta$-peptide aggregation and neurotoxicity. Inorg Chem 48: 5801-5809.

21. Marques ES, Salles DB, Maistro EL (2015) Assessment of the genotoxic/ clastogenic potential of coumarin derivative 6,7-dihydroxycoumarin (aesculetin) 
Citation: Arabuli L, Jezek R, Macek T, Lovecka P, Nikoleishvili E, et al. (2017) Solid-Phase Synthesis and In Vitro Cytotoxicity of New Peptide Functionalized Cyclencarboxymethylen and L-DOPA Hybrids. Med Chem (Los Angeles) 7: 398-405. doi: 10.4172/2161-0444.1000487

in multiple mouse organs. Toxicology Reports 2: 268-274.

22. Moffet RS (1964) Central nervous system depressants. VII pyridyl coumarins. J Med Chem 7: 446-449.

23. Kostova I, Raleva S, Genova P, Argirova R (2006) Structure-activity relationships of synthetic coumarins as HIV-1 inhibitors. Bioinorg Chem Appl 2006: 1-9.

24. Al-Haiza MA, Mosafa MS, El-Kady MY (2003) Synthesis and biological evaluation of some new coumarin derivatives. Molecules 8: 275-286.

25. Jung J, Kin J, Park OS (2001) A Convenient one-pot synthesis of 4-hydroxy coumarin, 4- hydroxy thiocoumarin and 4-hydroxy quinolin-2(1H)-one. Synth Commun 31: 1195-1200.

26. Vianna DK, Butols G, Meirelles G, Silva RV, Rocha A, et al. (2012) Evaluation of the Antioxidant Capacity of Synthesized Coumarins. Int J Mol Sci 13: 72607270.

27. Walkinshaw G, Waters CM (1995) Induction of apoptosis in catecholaminergic PC cells by L-dopa; implications for treatment of Parkinson's disease. J Chin Invest 95: 2458-2464.

28. De Leon-Rodriquez LM, Kovacz Z, Esquenda-Oliva AC, Miranda-Olvera AD (2006) Highly regioselective $\mathrm{N}$-trans symmetrical diprotection of cyclen. Tetrahedron Lett 47: 6937-6940.

29. Bellouard F, Chuburu F, Kervarec N, Toupet L, Triki S, et al. (1999) CisDiprotected cyclams and cyclens: a new route to symmetrically or asymmetrically 1,4-disubstituted tetraazamacrocycles and to asymmetrically tetrasubstituted derivatives. J Chem Soc Perkin Trans 23: 3499-3505.

30. Li C, Wong WT (2003) A Simple, Regioselective Synthesis of 1,4-Bis(tertbutoxycarbonylmethyl)- tetraazacyclododecane. J Org Chem 68: 2956-2959.
31. Yu M, Ryan TM, Ellis S, Bush Al, Triccas JA, et al. (2014) Neuroprotective peptide-macrocycle conjugates reveal complex structure-activity relationships in their interactions with amyloid $\beta$. Metallomics 6: 1931-1940.

32. Pallitto MM, Chanta J, Heinzelman P, Kiessling LL, Murphy RM (1999) Recognition sequence design for peptidyl modulators of beta-amyloid aggregation and toxicity. Biochemistry 38: 3570-3578.

33. Tjernbeng LO, Maslund J, Lindqvist F, Johansson J, Karlstrom AR, et al. (1996) Arrest of beta-amyloid fibril formation by a pentapeptide ligand. J Biolog Chem 271: 8545-8548.

34. Weber J, Keating GM (2009) Ropinirole prolonged release: in advanced Parkinson's disease. CNS Drugs 23: 81-90.

35. Djaldetti R, Melamed E (2001) New therapies for Parkinson's disease. J Neurol 248: 357-362.

36. Polt R, Porreca F, Szabo LZ, Bilski E (1994) Glycopeptide enkephalin analogues produce analgesia in mice: Evidence for penetration of the bloodbrain barrier. P Roc Natl Acad Sci USA 91: 7114-7118.

37. Bonina FP, Arenare L, Palagiano F, Saija A, Naia F, Trombetta DC (1999) Synthesis, stability and pharmacological evaluation of nipecotic acid prodrug. J Pharm Sci 88: 561-567.

38. Zhou T, Hider RC, Jenner P, Campbell B, Hobbs CJ, et al. (2013) Design, synthesis and antithrombotic evaluation of novel dabigatran prodrugs containing methyl ferulate. Bioorg and Medicinal Chem Lett 23: 5279-5282.

39. Zhou T, Hider RC, Jenner P, Campbell B, Hobbs CJ, et al. (2010) Design, synthesis and biological evaluation of L-dopa amide derivatives as potential prodrugs for the treatment of Parkinson's disease. European $\mathrm{J}$ Medicinal Chemistry 45: 4035-4042. 